\title{
Security management of innovation activity of an enterprise based on a multiple-factor approach
}

\author{
TATIANA ROMANCHIK \\ Department of Economics and Marketing \\ National Technical University «Kharkiv Polytechnic Institute» \\ Kirpicheva 2, Kharkov, 61002 \\ UKRAINE \\ MAYA CHERKASHINA \\ Department of Management and the military economy \\ National Academy of the National Guard of Ukraine \\ Zahysnykiv Ukrainy sq., 3, Kharkov \\ UKRAINE \\ OLENA SHAPOVAL \\ Department of Management and the military economy \\ National Academy of the National Guard of Ukraine \\ Zahysnykiv Ukrainy sq., 3, Kharkov \\ UKRAINE \\ OLENA KITCHENKO \\ Department of Economics and Marketing \\ National Technical University «Kharkiv Polytechnic Institute» \\ Kirpicheva 2, Kharkov, 61002 \\ UKRAINE \\ OKSANA HELIAROVSKA \\ Department of Computer Mathematics and Data Analysis \\ National Technical University «Kharkiv Polytechnic Institute» \\ Kirpicheva 2, Kharkov, 61002 \\ UKRAINE
}

\begin{abstract}
The introduction of innovations is carried out in conditions of uncertainty and is associated with a high degree of risk which affects the economic security of enterprises. The purpose of the research is to develop a methodology for selecting innovative enterprise projects that are optimal for investment. To achieve the goal we proposed to compare project evaluations in the external and internal environment by using a comparative analysis. In this case, the object of research is a portfolio of innovative projects where an indicator of internal competitiveness is calculated by taxonomic assessment for each project. Each project is evaluated to predict its level of market competitiveness by the analytic hierarchy process. The implementation of the proposed methodology will result in the selection of such innovative projects in the capacity of investment objects that simultaneously have a high level of internal and market competitiveness. Thus, the implementation of the proposed methodology will optimize the choice of areas of innovative activity of enterprises, which will significantly reduce the risk of innovation.
\end{abstract}

Key Words: - Innovation, competitiveness, economic security, multi-criterion, project, comparative analysis

Received: January 22, 2020. Revised: June 29, 2020. Accepted: July 6, 2020. Published: July 7, 2020. 


\section{Introduction}

Increased competition in all market segments is a sign of the current situation in the world economy. This determines the perception of innovative activity of market entities as the basis of their successful activity. Becoming a prerequisite for the development of the enterprise, innovative processes determine the acceleration of the scientific and technological process, rapid changes in fashion trends, fluctuations in market conditions and so on. Innovation activity is becoming a source of potential opportunities for economic entities, as well as a significant risk-generating factor. It creates the conditions for creating competitive advantages of companies and ensuring their high reputation, and also increases the number and level of threats that commodity producers have to face. This is due to the high degree of uncertainty in innovation. Its effectiveness directly depends on how correctly the priority vectors of innovative development are chosen, the main market trends, potential needs of consumers are accurately predicted and so on. The choice of areas of innovation and investment activity becomes an important issue for the enterprise in terms of the search for the optimal ratio between the level of attractiveness of innovation and the impact of the results of its implementation on the efficiency of processes.

Most often, the decision on the development of innovative activity in production is justified by the calculation of indicators of economic activity, which include indicators of production efficiency, financial and investment efficiency [12]. However, the process of introducing innovations also opens up other potential opportunities for the enterprise, which can be considered as prospects for achieving strategic guidelines. In this regard, when substantiating innovation development vectors, theoretical and practical issues of forecasting the efficiency and safety of innovative projects based on a multifactorial approach are of particular relevance to enterprises.

\section{Problem Formulation}

According to global statistics, over the past 5 years, almost $69 \%$ of the companies present in the market, to one degree or another, have experienced at least one corporate crisis. That is, two-thirds of companies operating in the market, for one reason or another, faced situations of economic instability. A crisis is not always limited to one phase. As a rule, it has a "long tail". If the crisis in the organization has the following waves, then in $47 \%$ it affects operating activities, and in $20 \%$ on the market position of the enterprise. According to a survey of 1,400 companies that survived the crisis, $19 \%$ of them were unable to fully restore their positions. This indicates the seriousness of the problem, the unpreparedness of enterprises to counter risk factors [21].

PwC Global conducted a research of 4,500 companies that have experienced critical processes. The leaders of these companies are confident that it is easier to ensure economic security and protect themselves from the crisis if there is information about risk factors and a clear methodology is developed to counter them.

In the course of the research, it was confirmed that crisis processes have a multifactorial nature. It is difficult to single out one or several factors that are crucial in ensuring the economic security of enterprises. Among the causes of the crisis, respondents called the most diverse, forming both within the enterprise and beyond. Those that were called most often are presented in fig. 1.

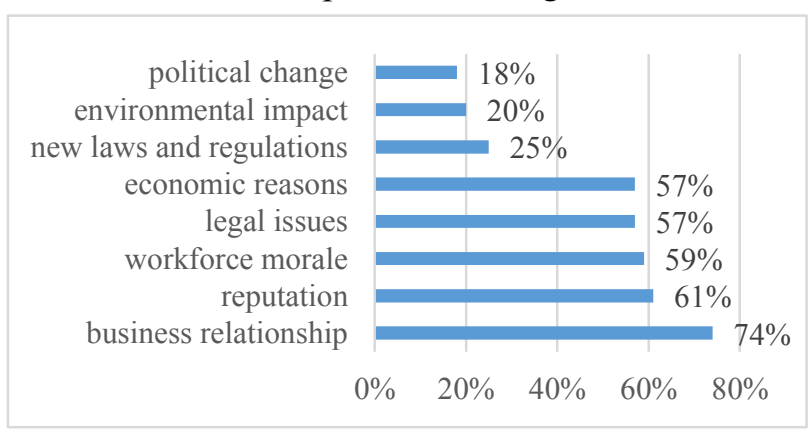

Fig. 1 Expert Opinions on the Causes of Crisis Processes [21]

According to 2084 respondents, the most important factors of internal formation that are responsible for the economic security of an enterprise are shown in Fig. 2

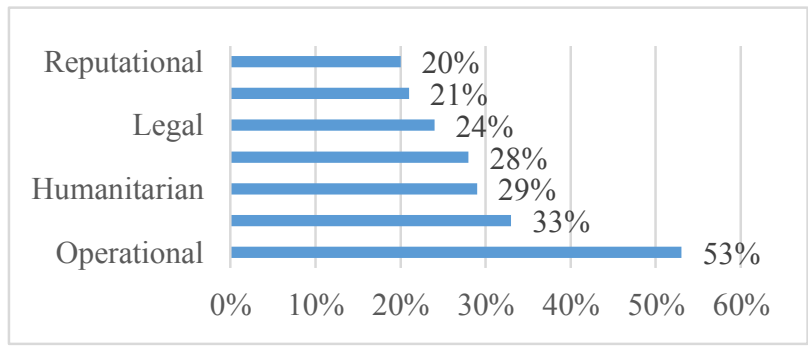

Fig. 2 Factors responsible for the economic security of enterprises [21]

It should be noted that less than a third of respondents named the issue of financial support among risk-generating factors. Most respondents consider insufficiently well-organized operational activities and technologies as the main risk factors that form the innovative potential of the enterprise. 
Active innovation is a global trend. In conditions of recession reigning in the economy, in order to maintain and strengthen their competitive positions, enterprises are forced to participate actively in innovative processes. In recent years, the world has seen a growth trend in investment in innovation. According to WIPO studies [6], the extent of use of intellectual property in 2017 and 2018 reached maximum levels. For the period 1996-2016 R\&D expenditures worldwide doubled, which surpassed global economic growth. In 2017, global R\&D expenditures showed the largest increase since 2011 and amounted to about $5 \%$.

On the scale of the activities of individual enterprises, the most important is the question of the effectiveness of transforming innovative resources into the results of innovation. According to the results of studies of the activities of companies actively involved in the implementation of innovative projects [30] «there is no long-term correlation between the amount of money a company spends on its innovation efforts and its overall financial performance».

Any innovative process cannot avoid many problems and risk-generating factors. First of all, this is associated with an increased risk of financial losses for the enterprise, which is caused by insufficient quality of marketing research, actions of competitors, errors in forecasting demand, miscalculations in the formation of a product strategy for production, etc. Errors in predicting the effectiveness of an innovative project can result from errors in assessing the market situation, which directly and indirectly depends on a complex of micro- and macroeconomic factors.

$31 \%$ of respondents among company executives when answering the question: "What stage of the innovation process is the most important?" called the creation of an idea. $35 \%$ of respondents consider the choice of the project as the most important stage. They emphasize the importance of meeting customer needs, the quality of ongoing processes, and the optimality of justification for decisions.

This determined the main directions in the ongoing study. The purpose of the study is to form a methodological approach to choosing the optimal list of innovative projects in order to increase the safety of innovative activities.

\subsection{Literature review}

The founder of the theory of economic development is the Austro-American economist Joseph A. Schumpeter [25], who is rightfully considered the founder of the economic theory of innovation. Distinguishing between the categories of "economic growth" and "economic development" became a fundamental contribution and formed the basis for understanding the role of innovation as a driving force for economic growth. According to the theory published by him, enterprises receive a significant advantage in implementing the mechanisms of economic development in a market economic system due to the decisive role of the entrepreneur-innovator. The fidelity of Schumpeter's understanding of the laws of economic development is increasingly confirmed in the works of representatives of world economic idea, which relate to later periods.

Dougherty \& Bowman [5] and Lu \& Lazonick [13] consider the continuous updating and maintenance of competitive advantages of products to be one of the most effective means of developing, strengthening and maintaining the competitive advantages of the enterprise. The importance of introducing technological innovation to maintain competitive advantage and ensure business success in a dynamic market environment is emphasized in the writings of Mauer [14], Qi, Wu, \& Zhang [22]. Based on an analysis of the activities of Italian manufacturing firms, B. H. Hall [7] proves the relationship between innovation and enterprise performance.

American researchers R. Nelson and S. Winter in the work "Evolutionary theory of economic change" explores the concept of "evolutionary economy" [17]. Considering the basic postulates defined by I. Schumpeter [25], the authors prove the laws of development of economic processes based on the generation and implementation of innovations and emphasize the main role of the innovative type of reproduction in the formation of the strategy of innovative development. Analyzing the main principles of the evolutionary economy, Salter and McKelvey [24] express the opinion that in conditions of competitive rivalry, which is accompanied by natural selection in the market, companies are forced to look for additional opportunities and have the desire and ability to implement them in their activities.

The purpose of introducing innovations is "the possibility to realize a potential economic value inherent in a new combination of resources and market needs, emerging from changes in the scientific or technological knowledge base, customer preferences, or the interrelationships between economic actors" [10]. Summing up this opinion, M. McKelvey [15] highlights the usefulness of innovations, mobilization of resources for introducing and using innovations, and the company's ability to take advantage of the useful 
effect that is synthesized among the components of innovative opportunities. Resource mobilization is associated with an increase in the financial costs of an enterprise, which always operates in conditions of financial deficit. Other of these components do not carry a clear certainty, which increases the likelihood of risk. D. Chernitsky and K. Kraft point to this aspect [2], emphasizing that research and development work are risky projects.

The team of authors [29] paid attention to the analysis of success factors of innovative projects. According to the results of the study [20], it was noted that the safety of innovative projects is laid at the design stage because of the complexity of this process. Scientific works [16]; [9]; [23] point out the need to ensure the process of innovation management and control over the implementation of innovative solutions in order to reduce their riskiness and ensure the safety of application. The essence of the safety of innovation is determined by the action of a complex of diverse indicators.

The authors of the article [11] explore the views of various scientists on factors that affect the effectiveness of technological innovations. They came to the conclusion that the degree of activity of innovative activities of the company should depend on the parameters of market demand. Thus, they emphasize the relationship between the results of innovation and the conditions of the market environment of the enterprise.

DeTienne and Koberg [3] emphasize that factors that influence the results of innovation are factors that are formed in the internal environment of the enterprise, as well as indicators of the external environment. The effectiveness of this concept underscore G. S. Hansen, and C. W. L. Hill [8], calling the market conditions, resources and company's capabilities incentives to innovate.

In the study [4], the authors emphasize that in order to increase the efficiency of innovation, it is necessary to build business models that should become a tool for integrating the components of the innovation process, such as ideas, technologies, markets, etc.

E. Penrose paid attention to the issue of increasing production capabilities based on the selection of optimal ways to use resources back in 1959 [19]. The development of the problem of optimizing the use of internal resources of the enterprise, taking into account information and knowledge obtained from the external environment, its adaptation to environmental conditions, found a response in [17], [28], [27]. Later, S. Brusoni with co-authors [1], Dodgson with co-authors [4] and others engaged in the search for business opportunities based on combining the internal capabilities of enterprises and the opportunities that are formed in the external environment.

So, despite the fact that when discussing the issues of optimizing the activities of enterprises, researchers emphasize the importance of taking into account the factors of various formation environments, at the moment there is no concept of combining two heterogeneous assessments into a single mechanism for substantiating decisions. Moreover, it is precisely the coordination of the evaluation of projects in internal and external environments that minimizes the risks associated with the introduction of innovations.

\section{Problem Solution}

Innovation activity of an enterprise is a complicated process that has many aspects. Its efficiency depends on the ability of the management to take a great number of factors, which are formed in both internal and external environment of an enterprise.

A potentially successful enterprise cannot allow itself to ignore the abovementioned innovation activity. In contemporary conditions, when scientific and technical progress is being developed at a rapid pace, the release of new product that has enhanced technic and technological characteristics is a valid type of approach that allows an enterprise to both keep its market standing and gain certain competitive edges. The conditions that may help stimulate artistic activities of employees, which are usually formed within the internal environment of an enterprise, give certain possibilities to improve all the functional components of its activity, or even get them to a whole new level. They also shape out the public image of an enterprise and transform into a source that forms its potential.

However, any innovation activity is not devoid of many problems, along with factors that may cause the inception of risks for an enterprise. First and foremost, it can be attributed to connections with the increasing risk of financial damages of an enterprise, that, in its turn, is driven by an insufficient quality of marketing research, as well as rival activities, mistakes being made in the process of demand forecasting, missteps during the formations of product stewardship of an enterprise, etc. Mistakes that are made at a stage of innovative project efficiency forecasting may be the result of mistakes in competitive assessment of the market, which directly and indirectly depends on a whole complex of both microeconomic and macroeconomic factors.

Potential results of innovative activity of an 
enterprise are formed under the influence of a whole array of managed and unmanaged factors, which are formed in the external environment (such as various business trends, changes in consumer interests, market conjuncture, introduction of new economic and political decisions to the market, macroeconomic processes). But it is important to note that the potential success on innovative activity is, first and foremost, the result of implementation of the decisions that are made by an enterprise management as well as various specialists and other employees of an enterprise [25]. This means that the factors of influence upon the results of innovative activities of various enterprises can be clearly differentiated between external factors and factors that are being formed within the internal environment of an enterprise.

The task of an enterprise during the forecast of results of innovative activities is to take the widest possible range of factors, which may influence said enterprise and its market activity. In this case, the potential efficiency of innovative activities is formed at the stage of choice of object to invest into. An enterprise is always considered to be in a state of lack of financial recourses. And so, this situation requires a steady and motivated approach to the justification of any decision considering the feasibility of implementation of some project into the production process. Based on the fact that the result of innovation depends on the correlation between factors that are formed in two different environments (that differ mostly by the very nature of their formation), their requirements and conditions, to be exact, must be carefully considered and coordinated when substantiating the directions of innovation activity of the enterprise:

1) if it is economically advisable to produce innovative product for the enterprise;

2 ) if the abovementioned innovative product will be accepted by the current market.

The success of the product on the market is determined during its implementation. We can consider the level of competitive performance of a product to be a good representation of the level, on which this product is met by its consumers. However, the most important for an enterprise are the answers for the following questions:

1. Is this profitable for the enterprise?

2. Is the enterprise capable of being able to afford it?

And so, the main focus of any enterprise should be on its financial performance. Any innovative activity requires the enterprise to invest a great quantity of resources into it. In cases, when the enterprise experiences lack of finances as well as a high level of risk, every innovative project from the whole project portfolio must be evaluated, while taking its attractiveness to the consumer and feasibility of implementation into consideration. However, along with such factors as profitability, efficiency and time of possible business impact, receiving some additional results is also quite important for an enterprise that focuses on innovation. These results can be described as strategic reference points of development. These references may arise in the form of the prospects of enhancing or maintaining the competitive position of an enterprise in the market, strengthening its public image, expanding markets that the enterprise covers, as well as other factors that are important in ensuring the viability of an enterprise. Thus, when forecasting the effectiveness of innovation activity, an enterprise should evaluate the complex of all possible factors that are being formed within its internal environment. The level of internal competitive performance of projects can serve as a comprehensive indicator, which can be considered capable of evaluating all the projects of an enterprise, according to all the factors that are important for the manufacturer.

In the classical sense of the term, competitive performance is the ability of an entity to occupy a dominant position because of the optimal combination of its most important characteristics. Internal competitive performance of an innovational project should be addressed in the light of its competitive advantages, in comparison to all the other projects of the enterprise. While judging possible internal competitive performance of the project, managers of the enterprise have an opportunity to determine the attractiveness of implementation of said project, while evaluating the potential beneficial effect for the enterprise itself. So, the internal competitive performance of the project can be considered as its potential or realized ability to operate effectively for a long-term duration with economic or any other benefit, to the enterprise.

\subsection{Methodology of research}

The evaluation of innovative and investment projects, in terms of their level of internal competitive performance, can be performed according to the stages, which are shown in fig. 3 .

An important stage of the evaluation of internal competitive performance of projects is compilation of a list of all the known factors that will be used in the following calculations and evaluations. 


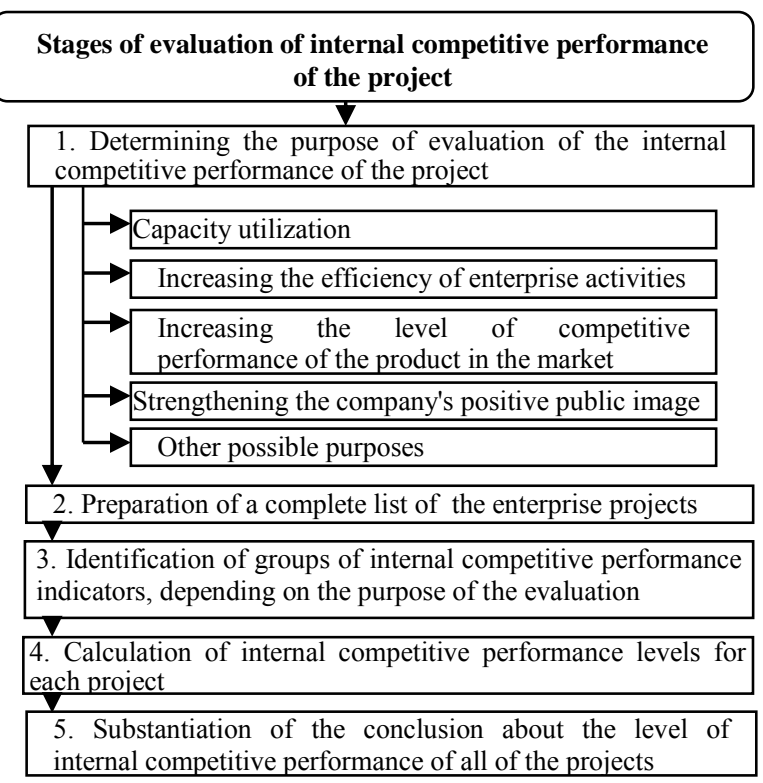

Fig. 3 Stages of evaluation of internal competitive performance of projects

For the development of reasonable and comprehensive classification of the factors, it is necessary to take the full composition of factors, which covers all the parameters that are important for the implementation of the project, into account. Among these factors, there are the level of profitability, availability and sufficiency of the technical and technological base, sources of attraction of investments, sufficiency of experienced personnel, the level of potential risk, etc. It should also be kept in mind, that the excess list of these features may create additional complexity during the calculations.

The factors of internal competitive performance are formed individually for each economic entity and have different degrees of importance in each separate case.

Factors of internal competitiveness are formed individually for each economic entity and have a different degree of importance in each case depending on the individual characteristics of the activities of enterprises and the properties of the projects being evaluated. The most difficult thing in all this process is to make a choice out of all the wide array of factors of the group of indicators that are considered the most important and can be chosen as a basis for further comparison.

Given that the most of factors at the moment of determination of internal competitive performance of projects have a qualitative nature, the hierarchy analysis technique (or HAT) can be considered the most rational method for their evaluation. For this, a hierarchical model, that will allow to reflect a relative degree of the interaction of elements in the hierarchy and to execute their consecutive pairwise comparison, should be built after all the needed factors of internal competitive performance of projects are determined.

The compulsory condition of this calculation is the adjustment of the relative importance of its elements.

The term "adjustment" here is understood to mean the following relations:

$$
\begin{gathered}
a_{i j} \cdot a_{j k}=a_{i k}, \\
a_{i i}=1, a_{j i}=\frac{1}{a_{i j}} .
\end{gathered}
$$

where $a_{i j}$ - are the elements of matrix of pairwise comparisons.

Pairwise comparison of elements of every level lets one choose the best possible option and calculate the degree of deviation of marks of other projects, as an indication of their internal competitive performance. According to the marks that were obtained as a result of this process, it is not hard to determine what projects are potentially profitable and should be invested in. The projects that have certain perspectives for further development can also be determined this way.

According to the marketing theory, the enterprise that is guided mainly by its own opportunities and possibilities is doomed to go bankrupt. The main guideline for activities of all the contemporary enterprises is the market. And that is why the most efficient way for evaluation of projects of any enterprise in the conditions of free market, is the determination of the level of market competitive performance of products that were made within the framework of a project.

Economic thought offers a comparatively large number of methods for assessing the level of competitive performance of products, among which it is difficult to identify a single one, which would be capable of satisfying all the requirements when evaluating a depersonalized product. The method of mathematical analysis that is based on taxonomic evaluation can be considered a fairly optimal approach in this regard. It allows one to compare the objects of the study, analyzing them with the help of a great number of incomparable parameters. The aim of the abovementioned taxonomic analysis in this regard is the comparison of different variants of products as multi-dimensional units, the choice of one that would be considered the closest to the socalled "perfect sample", as well as the determination of the degree of deviation of the obtained results from the ideal ones. Thus, by applying the method of taxonomic evaluation, it is possible to determine the competitive performance of a particular product 
within the market as objectively as possible, by applying the comparison of its various quantitative and qualitative characteristics that might be relevant to consumers among the target demographic.

A reasonable decision regarding the feasibility and safety of investing in an innovative project can be made by comparing the internal competitive performance of the innovative project and the level of competitive performance of the respective product in the market (Fig. 4). The internal competitive performance of the project thus serves as one of the main conditions for making the decision, whether to invest into it, or not.

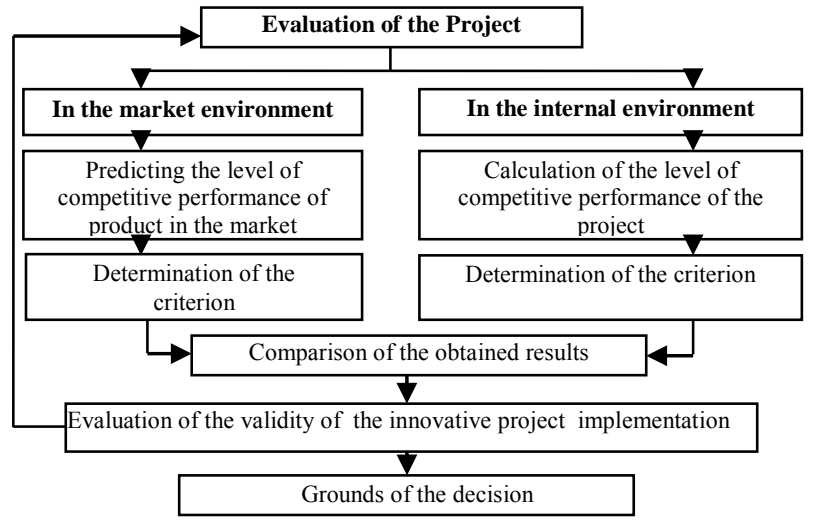

Fig. 4 The order of the grounds of the decision on investment into an innovative activity

For an enterprise, there is no reason to invest into a project, which implementation does not have some current or prospective economic validity. And on the contrary, vectors of activity that either have comparatively high prospects within the market, or those that have the ability to bring the enterprise to the whole new level of development, deserve special attention of managers and should be prioritized above others in terms of efficiency of implementation of innovations.

Thus, to justify the final decision regarding the investment attractiveness of a project, it is advisable to compare the estimates of the internal competitive performance of the projects (Q) and the potential competitive performance of the relevant products market that are currently in the market $(\mathrm{K})$ for the entire portfolio of projects that are considered as potential objects of investment.

The values of the levels of market and internal competitive performance of the projects are obtained through the use of many different methods, so the direct comparison of the calculated values is not entirely correct.

The mandatory condition for continuing the calculations is the choice of a base of comparison, namely, the limit values of internal and external competitive performance, which, in their turn, can be considered as a sufficient level of their development.

According to calculations by the method of hierarchy analysis, the values of levels of internal competitive performance of projects fall into the following range: $0<\mathrm{Q}_{\mathrm{i}}<1 ; \Sigma \mathrm{Q}_{\mathrm{i}}=1$. The criterion of internal competitive performance $\left(\mathrm{Q}_{\lim }\right)$ can be determined by the Pareto principle and the $\mathrm{ABC}$ analysis that is based on it, choosing the value on the boundary between the groups B and C for $\mathrm{Q}_{\lim }$ (sufficient level of indicator development).

For the measure of competitive performance in the market, the average weighted value of the potential market competitiveness of a product can be chosen to represent the criterion $\left(K_{\text {lim }}\right)$, while taking the possible volumes of its sales into account:

$$
K_{\lim }=\frac{\sum_{i=1}^{n} K_{i} \cdot f_{i}}{\sum_{i=1}^{n} f_{i}},
$$

where $K_{i}$ is the value of the level of competitive performance in the market for the product, marked as $\mathrm{i}$;

and $f_{i}$ is the quantity of the units of the product that are planned to be realized within a certain set period.

The methodology for determination of the strategic direction of innovation is presented in the form of a diagram in fig. 5 :

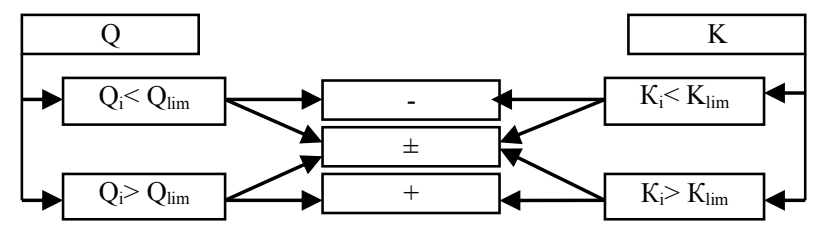

Fig. 5 The logic of justification of the investment into the innovative decision

The comparison of given values of both the competitive performance in the market and the internal competitive performance of innovative projects allows to identify the projects, which might be economically unprofitable for the enterprise to invest into, which, in its turn, may lead to a deterioration of market positions of the enterprise.

The most attractive projects are the ones that have both values highly rated. In a situation, when only one of the values is positive, the project needs further analysis.

Therefore, according to the data analysis, all the projects can be classified into three different groups, namely: 
1) $Q>Q_{\text {lim }} ; K>K_{\lim }$ - project with high priority value;

2) $Q<Q_{\lim } ; K<K_{\lim } \quad$ - project having no prospects, which development is not profitable;

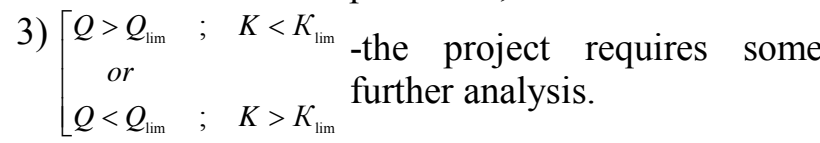

If no issues arise regarding the development of the first two project groups with both clearly pronounced assessments, then the third group includes projects that potentially have either a low level of competitive performance within the market or are relatively unfavorable to the enterprise at a relatively high level of development of the indicator. Precisely these projects require additional analysis of their potential success in the market and the impact of their implementation on the results of activities of the enterprise.

\subsection{Results}

The company is faced with the task of selecting projects the investment of which will be accompanied by minimal marketing risks. To evaluate the indicators that are involved in the calculation, additional research is necessary.

Assessment of the internal competitiveness of projects was carried out by the method of analytical hierarchy process. The main parameters by which the study was conducted are presented in table 1 .

Table 1 Key indicators of internal competitiveness of products

\begin{tabular}{|c|c|c|}
\hline $\begin{array}{c}\text { I hierarchy } \\
\text { level }\end{array}$ & II hierarchy level & III hierarchy level \\
\hline \multirow{14}{*}{$\begin{array}{l}\text { Project } \\
\text { Internal } \\
\text { Competitiv } \\
\text { eness } \\
\text { Factors }\end{array}$} & \multirow{5}{*}{$\begin{array}{l}\text { production and } \\
\text { financial }\end{array}$} & $\begin{array}{l}\text { technical and technological } \\
\text { support }\end{array}$ \\
\hline & & sources of investment \\
\hline & & $\begin{array}{l}\text { profitability and performance } \\
\text { indicators }\end{array}$ \\
\hline & & profitability of production \\
\hline & & resource \\
\hline & \multirow{5}{*}{$\begin{array}{l}\text { intellectual } \\
\text { socio- } \\
\text { environmental }\end{array}$} & innovative \\
\hline & & labor \\
\hline & & motivational \\
\hline & & \begin{tabular}{|l|l|} 
ecological compatibility of \\
production
\end{tabular} \\
\hline & & $\begin{array}{l}\text { ecological compatibility of a } \\
\text { product }\end{array}$ \\
\hline & \multirow{4}{*}{$\begin{array}{l}\text { aimed at external } \\
\text { result }\end{array}$} & Income sales of a product \\
\hline & & life cycle stage \\
\hline & & product competitiveness \\
\hline & & $\begin{array}{l}\text { impact on the image of the } \\
\text { enterprise }\end{array}$ \\
\hline
\end{tabular}

Table 2 The calculated values of the level of internal competitiveness

\begin{tabular}{|l|l|l|}
\hline \multicolumn{1}{|c|}{ Object of study } & $\begin{array}{c}\text { Level of internal } \\
\text { competitiveness, Q }\end{array}$ & Rank \\
\hline Project 1 & 0,290 & 1 \\
\hline Project 2 & 0,138 & 3 \\
\hline Project 3 & 0,090 & 6 \\
\hline Project 4 & 0,182 & 2 \\
\hline Project 5 & 0,121 & 4 \\
\hline Project 6 & 0,086 & 7 \\
\hline Project 7 & 0,093 & 5 \\
\hline
\end{tabular}

According to the $\mathrm{ABC}$ method, we determine the $\mathrm{Q}_{\lim }$ (Fig. 6)

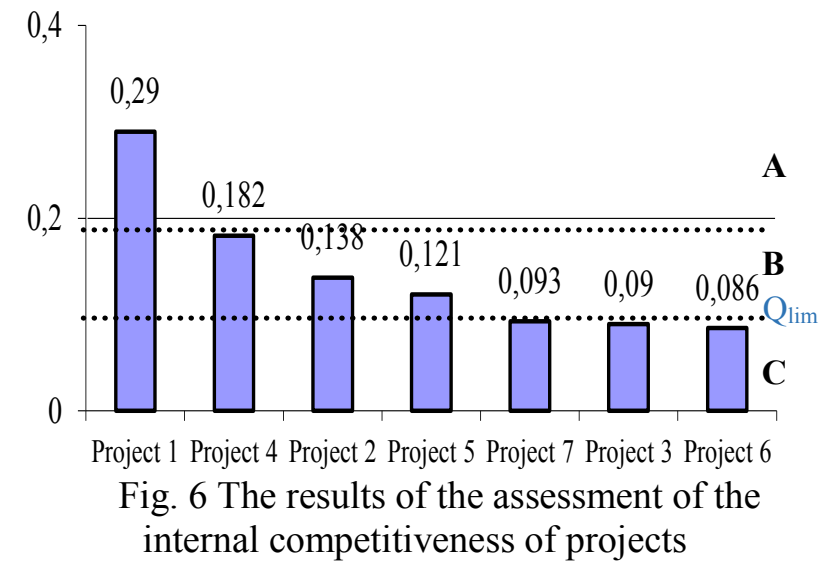

According to the results of calculations $\mathrm{Q}_{\lim }=$ 0,1 . Accordingly, products rated $\mathrm{Q}>0.1$ can be considered profitable for the company, production projects with $\mathrm{Q}<0.1$ - do not have a reasonable positive effect.

At the second stage, the indicator of market competitiveness of projects is calculated taking into account the risks of their implementation. Table 3 contains the initial data on which a comprehensive assessment of the safety of projects in the environment will be conducted.

Table 3 Values of indicators of market security of innovative projects

\begin{tabular}{|c|c|c|c|c|c|c|c|}
\hline \multirow{2}{*}{$\begin{array}{l}\text { Project safety } \\
\text { indicators }\end{array}$} & \multicolumn{7}{|c|}{ Project } \\
\hline & 1 & 2 & 3 & 4 & 5 & 6 & 7 \\
\hline $\begin{array}{l}\text { 1. The capacity of the } \\
\text { target market ( } \mathrm{mln} \text {. } \\
\text { UAH). }\end{array}$ & 300 & 270 & 170 & 330 & 300 & 190 & 280 \\
\hline $\begin{array}{l}\text { 2. Relevant level of } \\
\text { product } \\
\text { competitiveness }\end{array}$ & 3,8 & 3,12 & 3,44 & 2,97 & 3,18 & 3,92 & 3,31 \\
\hline $\begin{array}{l}\text { 3. The degree of } \\
\text { uniqueness of the } \\
\text { product (points) }\end{array}$ & 4 & 4 & 5 & 3 & 5 & 5 & 4 \\
\hline $\begin{array}{l}\text { 4. The possibility of } \\
\text { price maneuvering }(\%)\end{array}$ & 12,4 & 13,2 & 17,1 & 9,8 & 12,3 & 16,8 & 15,0 \\
\hline $\begin{array}{l}\text { 5. The willingness of } \\
\text { consumers to perceive } \\
\text { the product (points) }\end{array}$ & 8,13 & 7,43 & 8,76 & 7,71 & 8,17 & 8,22 & 7,73 \\
\hline $\begin{array}{l}\text { 6. The degree of } \\
\text { competition in the } \\
\text { market }\end{array}$ & 0,76 & 0,63 & 0,58 & 0,82 & 0,73 & 0,61 & 0,64 \\
\hline
\end{tabular}


Table 4 is a matrix of initial values, where $\mathrm{mj}$ is the average value of the indicator $i, \sigma_{j}$ is the estimate of the mean square deviation for each indicator:

Table 4 Matrix of initial values (Xi)

\begin{tabular}{|c|l|l|l|l|l|c|}
\hline \multirow{2}{*}{ Projects } & \multicolumn{7}{|c|}{ Project Safety Indicators } \\
\cline { 2 - 7 } & 1 & 2 & 3 & 4 & 5 & 6 \\
\hline 1 & 300 & 3,8 & 4 & 12,4 & 8,13 & 0,76 \\
\hline 2 & 270 & 3,12 & 4 & 13,2 & 7,43 & 0,63 \\
\hline 3 & 170 & 3,44 & 5 & 17,1 & 8,76 & 0,58 \\
\hline 4 & 330 & 2,97 & 3 & 9,8 & 7,71 & 0,82 \\
\hline 5 & 300 & 3,18 & 5 & 12,3 & 8,17 & 0,7 \\
\hline 6 & 190 & 3,92 & 5 & 16,8 & 8,22 & 0,6 \\
\hline 7 & 280 & 3,31 & 4 & 15 & 7,73 & 0,6 \\
\hline $\begin{array}{c}\text { Factor } \\
\text { type }\end{array}$ & + & + & + & + & + & - \\
\hline mj & 262,86 & 3,391429 & 4,285714 & 13,8 & 8,0214 & 0,67 \\
\hline$\sigma j$ & 55,476 & 0,327607 & 0,699854 & 2,446572 & 0,4054 & 0,09 \\
\hline
\end{tabular}

In this particular case, factors 1 to 5 are stimulants $(+)$, factor number 6 is a destimulant (-).

Table 5 is a matrix of standardized values obtained by normalizing the initial index.

Table 5 Matrix of standardized values of safety characteristics $(\mathrm{Zi})$

\begin{tabular}{|c|c|c|c|c|c|c|}
\hline \multirow{2}{*}{ Projects } & \multicolumn{7}{|c|}{ Project Safety Indicators } \\
\cline { 2 - 7 } & 1 & 2 & 3 & 4 & 5 & 6 \\
\hline 1 & 0,6695 & 1,2471 & $-0,4083$ & $-0,5722$ & 0,2678 & 1,05440 \\
\hline 2 & 0,1288 & $-0,829$ & $-0,408$ & $-0,2452$ & $-1,459$ & $-0,4686$ \\
\hline 3 & $-1,674$ & 0,1483 & 1,0206 & 1,34883 & 1,8218 & $-1,0544$ \\
\hline 4 & 1,2103 & $-1,286$ & $-1,837$ & $-1,6349$ & $-0,7682$ & 1,75734 \\
\hline 5 & 0,6695 & $-0,645$ & 1,0206 & $-0,6131$ & 0,3665 & 0,35147 \\
\hline 6 & $-1,313$ & 1,613 & 1,0206 & 1,22621 & 0,4898 & $-0,8201$ \\
\hline 7 & 0,3090 & $-0,2486$ & $-0,408$ & 0,49048 & $-0,719$ & $-0,8201$ \\
\hline $\mathrm{M}=$ & 0 & 0 & 0 & 0 & 0 & 0 \\
\hline $\mathrm{S}=$ & 1 & 1 & 1 & 1 & 1 & 1 \\
\hline & + & + & + & + & + & - \\
\hline $\mathrm{Zo}=$ & 1,2103 & 1,6134 & 1,0206 & 1,34883 & 1,8218 & $-1,0544$ \\
\hline
\end{tabular}

At the next stage, the distances of each point to the reference point, the average value and the standard deviation of the found distances, as well as the maximum statistical distance, the intermediate and final indicator of the external security of the projects are calculated. The calculation of the values is presented in table. 6 .

Table 6 - Calculation of taxonomic distances in the coordinate space

\begin{tabular}{|c|c|c|c|r|}
\hline \multirow{2}{*}{ Projects } & \multicolumn{3}{|c|}{ Distance to point Z } & \multirow{2}{*}{ Rank } \\
\cline { 2 - 4 } & Dio & Ci $^{*}$ & $\mathrm{Ci}$ & \\
\hline 1 & 1,1067083 & 0,4378277 & 0,562172 & 2 \\
\hline 2 & 1,7919766 & 0,7089283 & 0,291072 & 6 \\
\hline 3 & 1,2227032 & 0,4837167 & 0,516283 & 3 \\
\hline 4 & 2,1443109 & 0,8483162 & 0,151684 & 7 \\
\hline 5 & 1,2740132 & 0,5040155 & 0,495984 & 4 \\
\hline 6 & 1,0795464 & 0,4270821 & 0,572918 & 1 \\
\hline 7 & 1,3893817 & 0,5496568 & 0,450343 & 5 \\
\hline
\end{tabular}

The closer to the unit is the calculated value, the more the characteristics of the object of study correspond to the maximum level of security implementation. Thus, according to the results of the calculations, Project 6 has a minimum level of implementation risk. The calculated result of Project 4 is as far removed as possible from the ideal point and cannot be considered appropriate for implementation based on the result.

$\mathrm{K} \lim =0.452$. The criterion is calculated as a weighted average value taking into account the sales volume of the corresponding products.

To select innovative projects, the implementation of which is the most economically safe, we compare their assessments in the internal and external environment (Table 7).

Table 7 The degree of desirability of the development of production projects

\begin{tabular}{|l|c|c|c|c|l|}
\hline Projects & \multicolumn{2}{|c|}{$\begin{array}{c}\text { Level of } \\
\text { internal } \\
\text { competitive } \\
\text { ness, }\end{array}$} & \multicolumn{2}{|c|}{$\begin{array}{c}\text { Market } \\
\text { Competitive } \\
\text { ness, K }\end{array}$} & $\begin{array}{c}\text { Degree of desirability } \\
\text { project } \\
\text { implementation }\end{array}$ \\
\hline Project 1 & 0,290 & + & 0,562 & + & priority project \\
\hline Project 2 & 0,138 & + & 0,291 & - & $\begin{array}{l}\text { project requiring } \\
\text { further analysis }\end{array}$ \\
\hline Project 3 & 0,090 & - & 0,516 & + & $\begin{array}{l}\text { project requiring } \\
\text { further analysis }\end{array}$ \\
\hline Project 4 & 0,182 & + & 0,152 & - & $\begin{array}{l}\text { project requiring } \\
\text { further analysis }\end{array}$ \\
\hline Project 5 & 0,121 & + & 0,496 & + & priority project \\
\hline Project 6 & 0,086 & - & 0,573 & + & $\begin{array}{l}\text { project requiring } \\
\text { further analysis }\end{array}$ \\
\hline Project 7 & 0,093 & - & 0,450 & - & high risk project \\
\hline Criterion & 0,10 & 0,452 & \\
\hline
\end{tabular}

Table 7 clearly demonstrates that the implementation of Project 7 is not economically feasible and poses a threat to the economic interests of the enterprise. The safest is the implementation of Project 1 and Project 5, as they simultaneously meet the needs and capabilities of the enterprise and meet external security factors. Other projects carry a risk of their development and implementation.

According to statistical research data, in 2017, 2387 types of innovative products were introduced by industrial enterprises of Ukraine, $42 \%$ of which can be called successful projects. $23 \%$ of projects incurred losses to enterprises. The cost of direct losses, according to rough estimates, amounted to UAH 2070 million [26].

Comparison of the indicators of the internal competitiveness of innovative projects and the potential market competitiveness of the corresponding products can significantly reduce the risk of innovation. 


\section{Conclusion}

Innovative activities of enterprises involve a high level of risk. Sources of risks of innovation can be objective and subjective conditions of the external and internal environment. It is impossible to completely avoid threats in innovation, since innovation and risk are two interrelated categories, but the enterprise must anticipate and neutralize as much as possible the effect of harmful factors.

Making the wrong decision regarding the implementation of an innovative project can become a source of threat to the economic security of the enterprise. According to [21], up to $70 \%$ of innovation costs are spent at the stages of product development and selection. An enterprise cannot always overcome the mistakes made at the decisionmaking stage about which ideas should be introduced into development and production. When deciding on the feasibility of implementing innovative projects, a fairly large number of factors should be evaluated. To optimize this task, it is proposed to group all indicators of influence into two groups depending on the environment of their formation and evaluate the project in terms of its internal competitiveness and potential external competitiveness of the respective products. The optimal decision can be made by comparing the estimates obtained. At this stage, it is easier to exclude projects whose development and implementation carries economic risks and protect the company from the loss of time and financial resources.

Such an approach will further contribute to a clearer understanding of the indicators that determine the safety of innovative projects, will allow a detailed analysis of the factors of negative influence, and will also provide a more critical approach to justifying decisions on the implementation of innovative projects.

In financial terms, the application of the proposed approach will protect the company from investing risky innovative projects.

Further research will focus on optimizing the calculation of the values of economic security factors of innovative projects implemented by the enterprise.

\section{References:}

[1] Brusoni, S., Prencipe, A., Pavitt, K. Knowledge specialization, organizational coupling, and the boundaries of the firm: Why do firms know more than they make? Administrative Science Quarterly, №46(4), 2001, pp. 597-621. DOI: $10.2307 / 3094825$

[2] Czarnitzki, D., Kraft, K. Management control and innovative activity. Review of Industrial Organization, №24, 2004, pp. 1-24. https://doi.org/10.1023/B:REIO.0000031361.2 $7597.7 \mathrm{c}$

[3] DeTienne, R. D., Koberg, C. S. The impact of environmental and organizational factors on discontinuous innovation within hightechnology industries. IEEE Transactions on Engineering Management, №49(4), 2002, pp. 352-364. DOI: 10.1109 / TEM.2002.806719

[4] Dodgson, M., Gann, D., Phillips, N. The Oxford handbook of innovation management. Oxford University Press, Oxford, 2014. DOI: 10,1093 / oxfordhb / 9780199694945.001 .0001

[5] Dougherty, D., Bowman, E. H. The effects of organizational downsizing on product innovation. California Management Review, №37(4), 1995, pp. 28-44. Retrieved from https://journals.sagepub.com/doi/abs/10.2307/4 1165809

[6] Global Innovation Index (GII) 2019. https://www.wipo.int/edocs/pubdocs/ru/wipo_p ub_gii_2019 keyfindings.pdf

[7] Hall, B. H., Lotti, F., Mairesse, J. Evidence on the impact of R\&D and ICT investments on innovation and productivity in Italian firms. Economics of Innovation and New Technology, №22(3), 2013, pp. 300-328. https://doi.org/10.1080/10438599.2012.708134

[8] Hansen, G. S., Hill, C. W. L. Are institutional investors myopic? A time series study of four technology-driven industries. Strategic Management Journal, №12(1), 1991, pp. 1-16. https://doi.org/10.1002/smj.4250120102

[9] He, W., Ming, X. G., Ni, Q. F., Lu, W. F., Lee, B. H. A unified product structure management for enterprise business process integration throughout the product lifecycle. International Journal of Production Research, №44(9), 2006, pp. 1757-1776. DOI: 10.1080 / 00207540500445453

[10] Holmén, M., Magnusson, M., McKelvey, M. What are innovative opportunities? Industry and Innovation, №14(1), 2007, pp. 27-45. DOI: 10.1080/13662710601130830

[11] Li, Y., Liu, Y., Ren, F. Product innovation and process innovation in SOEs: evidence from the Chinese transition. The Journal of Technology Transfer, №32, 2007, pp. 63-85. https://doi.org/10.1007/s10961-006-9009-8

[12] Litvin, Z. Analysis of the effectiveness of innovative activities of the enterprise. Ekonomichnii Analiz, №11(2), 2012, pp. 316$319 . \quad$ Retrieved from http://nbuv.gov.ua/UJRN/ecan_2012_11\%282 $\% 29 \_64$ 
[13] Lu, Q., Lazonick, W. The organization of innovation in a transitional economy: Business and Government in chinese electronic publishing. Research Policy, №30(1), 2001, pp. 55-77. https://doi.org/10.1016/S00487333(99)00082-7

[14] Maurer, B. Innovation and investment under financial constraints and product market competition. International Journal of Industrial Organization, №17(4), 1999, pp. 455-476. https://doi.org/10.1016/S0167-7187(97)000477

[15] McKelvey, M. Firms navigating through innovation spaces: a conceptualization of how firms search and perceive technological, market and productive opportunities globally. Journal of Evolutionary Economics, №26, 2016, pp. 785-802. https://doi.org/10.1007/s00191-0160478-0

[16] Milewski, S. K., Fernandes, K. J., Mount, M. P. Exploring technological process innovation from a lifecycle perspective. International Journal of Operations \& Production Management, №35(9), 2015, pp. 1312-1331. https://doi.org/10.1108/IJOPM-02-2015-0105

[17] Nelson, R. The sources of economic growth. Harvard University Press, Cambridge, 1996. https://doi.org/10.1002/(SICI)10991468(199805)19:3<199::AIDMDE881>3.0.CO;2-1

[18] Nelson, R., Winter, S. An evolutionary theory of economic change. Cambridge, MA.: Belknap Press of Harvard University Press, 1982. https://doi.org/10.2307/3114818

[19] Penrose, ET The theory of the growth of the firm. Wiley, New York, 1959. DOI: $10.1093 /$ 0198289774.001 .0001

[20] Puthamont, G., Capt, S., Charoenngam, C. Strategic project selection in public sector: Construction projects of the Ministry of Defence in Thailand. International Journal of Project Management, №25(2), 2007, pp. 178188. https://doi.org/10.1016/j.ijproman.2006.05.001

[21] PwC Global Crisis Survey. https://www.pwc.com/gx/en/services/advisory/f orensics/global-crisis-survey/the-chainreaction-of-crisis.html

[22] Qi, D., Wu, W., Zhang, H. Shareholding structure and corporate performance of partially privatized firms: Evidence from listed Chinese companies. Pacific-Basin Finance Journal, №8(5), 2000, pp. 587-610. https://doi.org/10.1016/S0927-538X(00)000135

[23] Rodríguez-Segura, E., Ortiz-Marcos, I.,
Romero, J. J., Tafur-Segura, J. Critical success factors in large projects in the aerospace and defense sectors. Journal of Business Research, №69(11), 2016, pp. 5419-5425. DOI: 10.1016/j.jbusres.2016.04.148

[24] Salter, A., McKelvey, M. Evolutionary analysis of innovation and entrepreneurship: Sidney G. Winter-recipient of the 2015 Global Award for Entrepreneurship Research. Small Business Economics, №47, 2016, pp. 1-14. https://doi.org/10.1007/s11187-016-9702-4

[25] Schumpeter, J. The theory of economic development. Harvard University Press, Cambridge, 1934. Retrieved from https://ssrn.com/abstract=1496199

[26] State Statistics Service of Ukraine. http://www.ukrstat.gov.ua/

[27] Teece, D. Explicating dynamic capabilities: the nature and microfoundations of (sustainable) enterprise performance. Strategic Management Journal, №28(13), 2007, pp. 1319-1350. https://doi.org/10.1002/smj.640

[28] Teece, D.J., Pisano, G., Shuen, A. Dynamic capabilities and strategic management. Strategic Management Journal, №18(7), 1997, pp.509-533.

https://doi.org/10.1002/(SICI)1097-

0266(199708) 18:7<509::AID-

SMJ882>3.0.CO;2-Z

[29] Tulembayev, A., Jumadilova, S., Adilova, A., Seidaliyeva, D. Introducing project management system into enterprises of defense industry in Kazakhstan, Problems and Perspectives in Management, №17(2), 2019, pp. 527-540. DOI:10.21511/ppm.17(2).2019.41

[30] What the top innovators get right. https://www.strategy-

business.com/feature/What-the-TopInnovators-Get-Right?gko $=\mathrm{e} 7 \mathrm{cf} 9$

\section{Contribution of individual authors to the creation of a scientific article (ghostwriting policy)}

\section{Author Contributions:}

Tatiana Romanchik has developed methodology, creation of models.

Maya Cherkashina has managed and coordinated responsibility for the research activity planning and execution.

Olena Shapoval was responsible for the Statistics.

Olena Kitchenko has implemented the Algorithm.

Oksana Heliarovska has organized and executed visualization/data presentation. 


\section{Creative Commons Attribution License 4.0 (Attribution 4.0 International, CC BY 4.0)}

This article is published under the terms of the Creative Commons Attribution License 4.0

https://creativecommons.org/licenses/by/4.0/deed.en US 